\title{
Occurrence of hydrocarbon-utilising bacteria in oil-polluted arid soils in Sudan
}

\author{
Manal Elsayed Abdel-Rahman, Salma Yousif Sidahmed and Faisal Abdalla Sinada* \\ Department of Botany, Faculty of Science, University of Khartoum P O Box 321, \\ University of Khartoum Khartoum 11115, Sudan. \\ Email: fsinada@gmail.com
}

Received 2 March 2020; Received in revised form 14 April 2020; Accepted 6 August 2020

\begin{abstract}
Aims: This study aimed to isolate and identify hydrocarbon-utilising bacteria from oil- polluted sites and to develop a microbial consortium for use in pilot trial and commercial scale bioremediation treatment systems in the future.

Methodology and results: Ten hydrocarbon-utilising bacterial strains were isolated using enrichment culture technique from oil-polluted sites using crude oil as sole carbon source. The strains were tentatively identified on the basis of colony morphology, microscopic examination and biochemical characteristics. The growth of each strain was assessed by growing the bacteria in mineral salt medium amended with diesel oil as sole carbon source. The isolates exhibited differences in growth with the order of biomass production being Enterobacter sp. $\left(\mathrm{OD}_{620}=1.283\right)>$ Bacillus subtilis subsp. subtilis $\left(\mathrm{OD}_{620}=1.245\right)>$ Aerococcus sp. $\left(\mathrm{OD}_{620}=1.100\right)>$ Bacillus firmus $\left(\mathrm{OD}_{620}=0.970\right)>$ Corynebacterium sp. $\left(\mathrm{OD}_{620}=0.886\right)>$ Bacillus lentus $\left(\mathrm{OD}_{620}=0.743\right)>$ Micrococcus luteus $\left(\mathrm{OD}_{620}=0.656\right)>$ Bacillus subtilis $\left(\mathrm{OD}_{620}=0.367\right)>$ Bacillus cereus $\left(\mathrm{OD}_{620}=0.110\right)>$ Kocuria flavus $\left(\mathrm{OD}_{620}=0.065\right)$.

Conclusion, significance and impact of study: This study is a prerequisite for the design of future full-scale bioremediation treatment of oil-polluted sites using hydrocarbon-utilising bacteria. An efficient consortium was developed comprising the best three hydrocarbon-utilising strains, which include Enterobacter sp., Bacillus subtilis subsp. subtilis and Aerococcus sp. This efficient microbial consortium is suggested to be used in future to rehabilitate oil-polluted sites in Sudan.
\end{abstract}

Keywords: Crude oil, refinery oil sludge, hydrocarbon-utilising consortium, Sudan

\section{INTRODUCTION}

Petroleum oil has many benefits to human society. However, in line with oil development, particularly onshore exploration, it carries potential risks for plants, animals, and humans (Atlas, 1981). During the Gulf War in 1991, the release of eight million barrels of crude oil into the surrounding marine environment and Kuwaiti desert was an ecological disaster that led to serious environmental damage to the region (Al-Daher et al., 1998). Malallah et al. (1998), for example, studied damage caused by oil pollution to Kuwaiti desert flora and found that four flowering plants suffered from mutagenic modifications.

Accidental introduction of hydrocarbons from leaking pipeline or oil processing and storage facilities have been and will continue to be significant sources of environmental pollution (Morgan and Watkinson, 1989). Likewise, the release of crude oil and petroleum products through negligent disposal practices of wastes such as refinery oil sludge, have been shown to cause serious damage to natural ecosystems when improperly managed (Van Hamme et al., 2003).
A diverse number of microorganisms have the ability to degrade and utilise petroleum hydrocarbons as their sole carbon and energy sources (Leahy and Colwell, 1990; Atlas, 1991; Atlas and Bartha, 1992; Wang et al., 2011; Ahirwar and Dehariya, 2013; Panda et al., 2013). Such microorganisms have been isolated from various natural habitats severely contaminated with oil and over 200 different species of hydrocarbon-degrading microorganisms have been identified (Rahman et al., 2002; Survery et al., 2004; Nwaogu et al., 2008; Roy et al., 2014; Koshlaf and Ball, 2017).

For the past two decades, the discovery and development of petroleum oil in Sudan has resulted in large increase in the use of petroleum products. Improper handling represents a high risk of polluting the environment by petroleum hydrocarbons especially during crude-oil extraction, transportation, storage, refining of petroleum products and careless disposals of petroleum wastes (Xu et al., 2018). Unavoidable daily contamination has been the result of a rise of gasoline/diesel pumping station due to an increase in the number of vehicles in Khartoum and other cities. Spills of oil during tanker transfer, and leakage from underground storage tanks are 
the cause of groundwater contamination (Rahman et al., 2002; Limaa et al., 2019).

Different physical and chemical techniques have been applied worldwide to remove hydrocarbons from contaminated aquatic and terrestrial habitats. Physical remediation techniques including the use of different kinds of booms (Schrader, 1991) and inorganic absorbent (Adebajo et al., 2003) and oleophilic and hydrophobic sorbents have been employed to remove oils from aquatic environments (Deschamps et al., 2003). Chemical techniques include the use of dispersants (Lessard and Demarco, 2000), encapsulation (Khan et al., 2004) and chemical oxidation (Asghar et al., 2016). However, various physical and chemical methods have limited effectiveness with concomitant high operational costs and cause negative impacts on the environment (Singh and Chandra, 2014). Biological treatment (bioremediation), the use of hydrocarbon degrading microorganisms to treat the hydrocarbon contamination, is considered an alternative and less expensive method by oil companies to chemical and physical methods. Bioremediation is also a publicly acceptable method for the degradation of hydrocarbon pollutants to innocuous inorganic or mineral elements (Admon et al., 2001; Lynch and Moffat, 2005; Mikesková et al., 2012; Omotayo et al., 2012; Singh and Chandra, 2014; Sarkar et al., 2017).

In spite of the increasing information available on biodegradation of crude oil, the study of microbial degradation of petroleum hydrocarbons under tropical and sub-tropical conditions has received less attention than in temperate and polar regions. This is in part due to the paucity of information on the prevalence and geographical distribution of the hydrocarbon-degrading bacterial populations in soils under arid and semi-arid conditions (Chaillan et al., 2004; Adebusoye et al., 2007; Nwaogu et al., 2008; Boboye et al., 2010). Unlike temperate and polar regions, the constant warm temperatures in countries such as Sudan are expected to favour microbial activity throughout the year, thus offering favourable conditions for the enhancement of bioremediation. There is no field study of microbial degradation of petroleum hydrocarbons conducted in Sudan since the start of oil production in 1999. Additionally, no serious attempt has been made to tackle the problem of the highly contaminated brine (produced formation water) that is delivered to the surface along with petroleum oil during extraction. After separation from crude oil, the hydrocarbon-polluted produced water is stored in storage ponds until it can be decontaminated. Oily petroleum refinery sludges that are generated in Sudan by, for example, the Khartoum Refinery Company, require similar attention.

The present study aimed to screen oil-polluted sites in Sudan and examine the diversity of hydrocarbon-utilising bacteria in a preliminary study. The study explored the possibility of selected single bacterial species and mixed consortia of indigenous isolates to utilise diesel oil under controlled laboratory conditions. The prevalent hydrocarbon-utilising bacteria were identified, characterized and preserved for further use. The work will ultimately identify an efficient microbial consortium to be recommended for use in future decontamination trials of oil-polluted sites in Sudan.

\section{MATERIALS AND METHODS}

\section{Source of oil utilising bacteria}

Soil samples were randomly collected to $10 \mathrm{~cm}$ depths from: (i) crude-oil contaminated soil in Heglig Central Processing Facility, Heglig oil field ( $9^{\circ} 53^{\prime} 00^{\prime \prime} \mathrm{N} 29^{\circ} 50^{\prime} 00^{\prime \prime}$ E), (ii) Shendi local petrol filling station in Khartoum North $\left(15^{\circ} 37^{\prime} 44^{\prime \prime} \mathrm{N} 32^{\circ} 37^{\prime} 33^{\prime \prime} \mathrm{E}\right)$ and (iii) dumping site of the oily sludge of the Khartoum Oil Refinery at Algaili, $45 \mathrm{~km}$ north of Khartoum (16 $\left.6^{\circ} 44^{\prime \prime} \mathrm{N} 32^{\circ} 41^{\prime} 18^{\prime \prime} \mathrm{E}\right)$. The samples were collected in pre-sterilised glass bottles and transported to the laboratory within $5 \mathrm{~h}$ of sampling and stored at $4{ }^{\circ} \mathrm{C}$ until further analyses.

\section{Medium composition}

Mineral salt medium (MSM) was used as the enrichment medium supplemented with $1 \%(\mathrm{v} / \mathrm{v})$ Heglig Nile Blend (HNB) crude oil as sole carbon source for isolation of hydrocarbon-utilising bacteria. The composition of MSM is that of Zajic and Supplisson (1972) and was used throughout the study. HNB crude oil was obtained from Khartoum Oil Refinery at Algaili. The isolated bacteria were grown on the MSM. The $\mathrm{pH}$ of the medium was adjusted to 7.4 using $6 \mathrm{~N}$ hydrochloric acid or $1 \mathrm{~N}$ sodium hydroxide.

\section{Enrichment and isolation of pure cultures of hydrocarbon-utilising bacteria}

Hydrocarbon-utilising bacteria were isolated and purified using the enrichment procedure described by Ganesh and Lin (2009) with some modification. In brief, $1 \mathrm{~g}$ soil sample was added into $100 \mathrm{~mL}$ of MSM that contains $1 \%(\mathrm{v} / \mathrm{v})$ HNB crude oil as sole carbon source in $250 \mathrm{~mL}$ Erlenmeyer flasks. The flasks were then shaken for seven days at $170 \mathrm{rpm}$ at $30{ }^{\circ} \mathrm{C} \pm 2{ }^{\circ} \mathrm{C}$. Serial dilutions were carried out for all samples and $1 \mathrm{~mL}$ of each dilution was streaked on MSM agar containing 1\% (v/v) HNB crude oil as sole carbon source. The plates were incubated at 30 ${ }^{\circ} \mathrm{C} \pm 2{ }^{\circ} \mathrm{C}$ for 3-7 days. Colonies of hydrocarbon-utilising bacteria were randomly picked and further purified by streaking onto nutrient agar plates for several times until pure colonies were obtained. The purified isolates were preserved on slants of nutrient agar and kept in a refrigerator at $4{ }^{\circ} \mathrm{C}$ and subcultured every month until ready to use. For long term preservation, the isolates were stored in $50 \%$ glycerol at $-20 \stackrel{\circ}{\circ}$

\section{Identification and characterisation of bacterial isolates}

Ten purified hydrocarbon-utilising bacterial strains which were isolated from the contaminated soil were given the letters: A (HOF 1.4), B (HOF 1.14), C (SPS 3.10), D (HOF 
1.23), E (HOF 1.26,), F (HOF 2.17), G (ERS 1), H (SPS 3.1), I (SPS 3.14), and J (SPS 3.30). The isolates were characterised with tentative identification to species/genus according to standard laboratory and taxonomic manuals on the basis of morphological characteristics of the cells and colonies as well as different types of biochemical tests such as Gram staining, endospore staining, oxidase test, catalase test, oxidation fermentation, hydrogen sulphide production test, nitrate reduction test, indole test, methyl-red test (MR), Voges-Proskauer test (VP), citrate utilisation test, triple sugar iron agar test, starch hydrolysis test and urease test (Holt et al., 1994; Cappuccino and Sherman, 2014). In this study, no genetic analyses were done.

\section{Capabilities of the ten purified bacterial strains to grow in diesel oil by measuring turbidity of the culture broth}

The capabilities of the 10 isolates to grow in refined diesel oil were tested and compared. The diesel oil was obtained from a local petrol filling station and stored in dark bottle at $30{ }^{\circ} \mathrm{C} \pm 2{ }^{\circ} \mathrm{C}$ throughout the study and the diesel oil was filter sterilized using cellulose membrane filter, pore size $0.2 \mu \mathrm{m}$, before it is used. In this study, the growth of the bacterial isolates in MSM containing $1 \%$ of diesel oil was considered having the ability to utilise the diesel oil, which was assessed by measuring the optical density of the liquid medium at $620 \mathrm{~nm}$ at the end of incubation period using spectrophotometer (Apel model PD-303). Testing involved adding $1 \mathrm{~mL}$ of culture broth from each bacterial isolate (OD equivalent to 1.0 at $620 \mathrm{~nm}$ ) to $250 \mathrm{~mL}$ Erlenmeyer flask containing $100 \mathrm{~mL}$ sterile MSM supplemented with $1 \%$ diesel oil as the sole carbon source. The flasks were stoppered with cotton wool stoppers and kept on a shaker at $170 \mathrm{rpm}$ at $30^{\circ} \mathrm{C} \pm 2^{\circ} \mathrm{C}$ for seven days. All media and glassware were sterilized by autoclaving for $15 \mathrm{~min}$ at $121^{\circ} \mathrm{C}$. Non-inoculated flasks and flasks without diesel oil served as controls. All treatments were conducted in duplicate. The optical density was recorded at the end of the incubation period at $620 \mathrm{~nm}$ to estimate bacterial growth and biomass. The growth was categorized as: (i) excellent growth of bacteria $\left(\mathrm{OD}_{620}=0.81->1.0\right)$ denoted by ++++ indicating very high hydrocarbon-utilising capability (ii) high growth of bacteria $\left(\mathrm{OD}_{620}=0.61-0.80\right)$ denoted by +++ indicating high hydrocarbon-utilising capability (iii) moderate growth of bacteria $\left(\mathrm{OD}_{620}=0.41-0.60\right)$ denoted by ++ indicating moderate hydrocarbon-utilising capability (iv) low growth of bacteria $\left(\mathrm{OD}_{620}=<0.40\right)$ denoted by + indicating low hydrocarbon-utilising capability (Rahman et al., 2002).

\section{Preparation of the best bacterial consortium for utilisation of diesel oil}

One $\mathrm{mL}$ from each bacterial broth was transferred into a separate $250 \mathrm{~mL}$ Erlenmeyer flask containing $100 \mathrm{~mL}$ sterile MSM medium (Zajic and Supplisson, 1972) supplemented with $1 \%$ diesel oil. The flasks were closed with cotton wool stoppers and kept on a shaker at 170 rpm at $30{ }^{\circ} \mathrm{C} \pm 2{ }^{\circ} \mathrm{C}$ until the optical density was approximately 1.0 at $620 \mathrm{~nm}$. In this study seven bacterial consortia were prepared. Each of the seven consortia was prepared by mixing together $1 \mathrm{~mL}$ of the pure culture broth from each of three or four bacterial isolates. Six consortia were prepared at random and labelled as $\mathrm{HBI}$, EGC, HBEF, IEFG, HGCl, and HEIG. One system (HBE) contained a consortium representing a mixture of the best three hydrocarbon-utilising bacteria isolated from this study. The overall growth of the bacterial strains comprising each consortium to survive in $1 \%$ diesel oil was assessed as outlined above to choose the best consortium for further studies.

\section{RESULTS AND DISCUSSION}

The hydrocarbon-utilising bacteria were obtained by culture enrichment technique with Heglig Nile Blend (HNB) crude oil as sole carbon and energy source. Pure cultures of 10 bacteria capable of utilising crude oil hydrocarbons as sole carbon source were successfully isolated under aerobic conditions from three different habitats contaminated with petroleum hydrocarbons. Table 1 shows that the growth performance of the 10 identified strains in MSM with diesel oil arranged in ascending order, exhibited noticeable differences varying from low to very high growth.

Tables 2 and 3 show the morphological characteristics of the 10 isolates as well as the results of biochemical tests. It is worth noting that the genera and species presented have been reported in the literature as typical heterotrophic bacteria present in the oil contaminated soils and capable of degrading hydrocarbons (Rahman et al., 2002; Survery et al., 2004; Hunter et al., 2005; Toledo et al., 2006; Nwaogu et al., 2008; Sathishkumer et al., 2008; Al-Saleh et al., 2009; Boboye et al., 2010; Roy et al., 2014; Koshlaf and Ball, 2017). Table 2 shows that 9 out of 10 isolates were Gram positive bacteria belonging to the five genera identified as Bacillus, Micrococcus, Corynebacterium, Kocuria and Aerococcus. The one Gram negative isolate belongs to the genus Enterobacter. The genus Bacillus dominated with 5 isolates; several other studies have shown dominance of Bacillus spp. from crude oil contaminated soils and soils from petrol stations. ljah and Antai (2003) attributed the prevalence and survival of Bacillus in soil samples with high concentrations of hydrocarbons up to $40 \%$ to the possession of resistant endospores.

The seven isolates with the highest growth on MSM (Table 1) were chosen to construct 7 consortia to test growth in diesel oil under controlled laboratory conditions (Table 4). The growth performance of these 7 isolates was in the order Enterobacter sp.> Bacillus subtilis subsp. subtilis> Aerococcus sp.> Bacillus firmus $>$ Corynebacterium sp.> Bacillus lentus> Micrococcus luteus (Table 1). The top 3 isolates with highest growth were chosen to formulate the consortium HBE (number 7, Table 4). In addition, another 6 consortia (consortia number 1-6, Table 4) of 3-4 isolates were constructed from these 
Malays. J. Microbiol. Vol 16(6) 2020, pp. 469-476

DOI: http://dx.doi.org/10.21161/mjm.200751

Table 1: The growth performance of the ten identified strains in mineral salt medium (MSM) with $1 \%$ diesel oil at optical density $620 \mathrm{~nm}\left(\mathrm{OD}_{620}\right)$.

\begin{tabular}{ccccc}
\hline $\begin{array}{c}\text { Represented } \\
\text { letter }\end{array}$ & Bacterial strains & Source of isolate & OD $_{620^{\mathrm{a}}}$ & $\begin{array}{c}\text { Bacterial } \\
\text { growth }^{\mathrm{b}}\end{array}$ \\
\hline A & Kocuria flavus & Heglig field & $0.065 \pm 0.047$ & + \\
D & Bacillus cereus & Heglig field & $0.110 \pm 0.040$ & + \\
J & Bacillus subtilis & S. P. station & $0.367 \pm 0.001$ & ++ \\
I & Micrococcus luteus & S. P. station & $0.656 \pm 0.017$ & +++ \\
C & Bacillus lentus & Heglig field & $0.743 \pm 0.013$ & +++ \\
G & Corynebacterium sp. & R. sludge & $0.886 \pm 0.016$ & ++++ \\
F & Bacillus firmus & Heglig field & $0.970 \pm 0.047$ & ++++ \\
E & Aerococcus sp. & Heglig field & $1.100 \pm 0.014$ & ++++ \\
B & Bacillus subtilis subsp. subtilis & Heglig field & $1.245 \pm 0.001$ & ++++ \\
H & Enterobacter sp. & S. P. station & $1.283 \pm 0.017$ & ++++ \\
\hline
\end{tabular}

Heglig field = Heglig oil field; R. sludge = Refinery sludge; S. P. station = Shendi petrol station

${ }^{a}$ Data represents averages \pm standard deviation (SD) of duplicate samples after incubation for seven days.

bexcellent growth of bacteria $\left(\mathrm{OD}_{620}=0.81->1.0\right)$ denoted by ++++ indicating very high hydrocarbon-utilising capability; high growth of bacteria $\left(\mathrm{OD}_{620}=0.61-0.80\right)$ denoted by +++ indicating high hydrocarbon-utilising capability; moderate growth of bacteria $\left(\mathrm{OD}_{620}=0.41-\right.$ $0.60)$ denoted by ++ indicating moderate hydrocarbon-utilising capability; low growth of bacteria $\left(O D_{620}=<0.40\right)$ denoted by + indicating low hydrocarbon-utilising capability

seven isolates to test and compare growth in diesel oil Table 4 shows that consortia 5,6 and 7 achieved the highest optical densities of $0.880,0.886$, and 0.940 respectively. However, the optical densities of these best three consortia (Table 4) were slightly lower compared to the top 3 individual strains that were tested singly in diesel oil (Table 1).

According to Varjani (2017), petroleum hydrocarbons utilizing microorganisms are widely distributed in nature and that they naturally biodegrade pollutants and thereby remove pollutants from the environment. Varjani et al. (2015) developed a hydrocarbon utilizing bacterial consortium consisting of four bacterial isolates that was found to be good at degrading crude oil. Many authors are in the opinion that mixed bacterial populations are superior to single cultures in degradation of petroleum hydrocarbons due to different degradative enzymes and pathways occurring in different members of the consortium (Leahy and Colwell, 1990; Bouchez et al., 2000; Mishra et al., 2001; Vinas et al., 2002; Gallego et al., 2007; Cerqueira et al., 2011; Malik and Safia, 2012; Santisi et al., 2015; Patowary et al., 2016).

Jasmine and Mukherji (2014) pointed out that the use of mixed bacterial populations is more effective than single bacterial populations because of broad enzymatic capacities, synergistic effect and co-metabolism in the degradation of complex mixtures of hydrocarbons. Sarkar et al. (2013) and Patowary et al. (2016) indicated that for a microbial consortium to achieve higher degradation, the bacterial mixed populations must be compatible with each other without any antagonism among them. It is possible that one species outgrows the others in the system used and one would need to use genetic analyses such as DNA sequencing following extraction to identify and provide information on the composition of microbial communities.

In the present study, the growth of the three individual isolates: Enterobacter sp., Bacillus subtilis subsp. subtilis and Aerococcus sp. in diesel oil obtained OD620 1.1001.283 , which is slightly higher than consortia of three to four isolates (Tables 1 and 4). From Table 4, the best consortium to grow in MSM with $1 \%$ of diesel oil is made up from these three bacterial isolates attaining OD 0.940 . It is interesting to note that this consortium of three bacteria showed higher growth $\left(\mathrm{OD}_{620} \mathrm{0.940}\right)$ than the consortium that consists of four isolates $\left(\mathrm{OD}_{620} 0.880\right)$ that included Bacillus firmus as an added member to the consortium of the three isolates (Table 4). An assumption may be made that by adding the fourth strain ( $B$. firmus) to the selected consortium of three strains, an antagonistic effect is exerted. However, this assumption must be verified by carrying out antagonistic tests to determine if there is any growth inhibition from every single isolate toward other strains. We recommend to screen isolates of the consortium for the production of quorum sensing signal molecules in future work, in order to illustrate synergistic and antagonistic effect. In this study, the consortium which consists of Enterobacter sp., Bacillus subtilis subsp. subtilis and Aerococcus sp. possessing good growth in diesel oil is useful for crude oil degradation in laboratory and field studies in the future. 
Malays. J. Microbiol. Vol 16(6) 2020, pp. 469-476

DOI: http://dx.doi.org/10.21161/mjm.200751

Table 2: Morphological and cultural characteristics of the bacterial strains isolated from three different habitats in this study.

\begin{tabular}{|c|c|c|c|c|c|c|c|c|c|c|c|}
\hline $\begin{array}{c}\begin{array}{c}\text { Represented } \\
\text { letter }\end{array} \\
\end{array}$ & Bacteria & $\begin{array}{l}\text { Colony } \\
\text { shape }\end{array}$ & Colour & Surface & Elevation & Margin & Opacity & Size & Gram & Endospore & $\begin{array}{c}\text { Cell } \\
\text { shape }\end{array}$ \\
\hline $\mathrm{A}$ & Kocuria flavus & circular & yellow & $\mathrm{n} / \mathrm{a}$ & convex & entire & transparent & small & + & - & coccus \\
\hline B & $\begin{array}{l}\text { Bacillus subtilis } \\
\text { subsp. subtilis }\end{array}$ & irregular & cream & $\mathrm{n} / \mathrm{a}$ & flat & undulate & transparent & large & + & + & rod \\
\hline C & Bacillus lentus & circular & cream & $\mathrm{n} / \mathrm{a}$ & flat & entire & transparent & medium & + & + & rod \\
\hline D & Bacillus cereus & circular & cream & $\mathrm{n} / \mathrm{a}$ & flat & entire & transparent & medium & + & + & rod \\
\hline $\mathrm{E}$ & Aerococcus sp. & circular & orange & $\mathrm{n} / \mathrm{a}$ & flat & entire & transparent & small & + & - & coccus \\
\hline $\mathrm{F}$ & Bacillus firmus & circular & cream & $\mathrm{n} / \mathrm{a}$ & flat & entire & transparent & small & + & + & rod \\
\hline G & $\begin{array}{l}\text { Corynebacterium } \\
\text { sp. }\end{array}$ & irregular & cream & granular & umbonate & serrate & transparent & - & + & - & rod \\
\hline $\mathrm{H}$ & Enterobacter sp. & circular & white & smooth & convex & entire & transparent & - & - & - & short rod \\
\hline I & $\begin{array}{l}\text { Micrococcus } \\
\text { luteus }\end{array}$ & circular & yellow & smooth & convex & entire & transparent & - & + & - & coccus \\
\hline $\mathrm{J}$ & Bacillus subtilis & circular & cream & smooth & raised & serrate & transparent & - & + & + & rod \\
\hline
\end{tabular}

$\mathrm{n} / \mathrm{a}=$ not available; $(+)=$ positive $(-)=$ negative

Table 3: Biochemical characteristics of the bacterial strains isolated from hydrocarbon contaminated habitats.

\begin{tabular}{|c|c|c|c|c|c|c|c|c|c|c|c|c|}
\hline $\begin{array}{c}\begin{array}{c}\text { Represented } \\
\text { letter }\end{array} \\
\end{array}$ & Bacteria & $\mathrm{H}_{2} \mathrm{~S}$ & Glucose & $\begin{array}{l}\text { MR } \\
\text { test }\end{array}$ & $\begin{array}{l}\mathrm{VP} \\
\text { test }\end{array}$ & $\begin{array}{c}\text { Indole } \\
\text { test }\end{array}$ & $\begin{array}{c}\text { Urease } \\
\text { test }\end{array}$ & $\begin{array}{c}\text { Citrate } \\
\text { test }\end{array}$ & $\begin{array}{c}\text { Catalase } \\
\text { test }\end{array}$ & $\begin{array}{c}\text { Oxidase } \\
\text { test }\end{array}$ & $\begin{array}{c}\text { Nitrate } \\
\text { test }\end{array}$ & $\begin{array}{c}\text { Oxidation } \\
\text { lactose/starch }\end{array}$ \\
\hline $\bar{A}$ & Kocuria flavus & - & - & + & - & - & - & + & + & - & $\mathrm{n} / \mathrm{a}$ & - \\
\hline B & $\begin{array}{l}\text { Bacillus subtilis } \\
\text { subsp. subtilis }\end{array}$ & - & + & - & + & - & - & + & + & + & $\mathrm{n} / \mathrm{a}$ & - \\
\hline C & Bacillus lentus & - & + & + & - & - & + & - & + & - & $\mathrm{n} / \mathrm{a}$ & - \\
\hline D & Bacillus cereus & - & + & - & + & - & - & + & + & - & $\mathrm{n} / \mathrm{a}$ & - \\
\hline $\mathrm{E}$ & Aerococcus sp. & - & + & + & - & - & - & + & + & - & $\mathrm{n} / \mathrm{a}$ & + \\
\hline $\mathrm{F}$ & Bacillus firmus & - & + & + & - & - & - & - & + & + & $\mathrm{n} / \mathrm{a}$ & - \\
\hline G & Corynebacterium sp. & - & + & + & - & - & + & + & + & + & + & - \\
\hline $\mathrm{H}$ & Enterobacter sp. & - & - & - & + & - & + & + & + & - & + & + \\
\hline 1 & Micrococcus luteus & - & - & + & - & - & - & - & + & - & + & - \\
\hline $\mathrm{J}$ & Bacillus subtilis & - & - & - & + & - & + & + & + & - & + & + \\
\hline
\end{tabular}

$\mathrm{n} / \mathrm{a}=$ not available; $(+)=$ positive; $(-)=$ negative 
Malays. J. Microbiol. Vol 16(6) 2020, pp. 469-476

DOI: http://dx.doi.org/10.21161/mjm.200751

Table 4: The growth performance of the ten identified strains in mineral salt medium (MSM) with $1 \%$ diesel oil at optical density $620 \mathrm{~nm}\left(\mathrm{OD}_{620}\right)$.

\begin{tabular}{|c|c|c|c|c|}
\hline \multicolumn{2}{|c|}{$\begin{array}{l}\text { Consortia numbers and } \\
\text { represented letters of isolates }\end{array}$} & Mixtures of consortia & $\mathrm{OD}_{620^{\mathrm{a}}}$ & $\begin{array}{l}\text { Bacterial } \\
\text { growth }^{\mathrm{b}}\end{array}$ \\
\hline consortium (1) & EGC & $\begin{array}{l}\text { Aerococcus sp. } \\
\text { Corynebacterium sp. } \\
\text { Bacillus lentus }\end{array}$ & $0.561 \pm 0.078$ & ++ \\
\hline consortium (2) & IEFG & $\begin{array}{l}\text { Micrococcus luteus } \\
\text { Aerococcus sp. } \\
\text { Bacillus firmus } \\
\text { Corynebacterium sp. }\end{array}$ & $0.631 \pm 0.009$ & +++ \\
\hline consortium (3) & HEIG & $\begin{array}{l}\text { Enterobacter sp. } \\
\text { Aerococcus sp. } \\
\text { Micrococcus luteus } \\
\text { Corynebacterium sp. }\end{array}$ & $0.662 \pm 0.103$ & +++ \\
\hline consortium (4) & $\mathrm{HGCl}$ & $\begin{array}{l}\text { Enterobacter sp. } \\
\text { Corynebacterium sp. } \\
\text { Bacillus lentus } \\
\text { Micrococcus luteus }\end{array}$ & $0.717 \pm 0.009$ & +++ \\
\hline consortium (5) & HBEF & $\begin{array}{l}\text { Enterobacter sp. } \\
\text { Bacillus subtilis subsp. subtilis } \\
\text { Aerococcus sp. } \\
\text { Bacillus firmus }\end{array}$ & $0.880 \pm 0.053$ & ++++ \\
\hline consortium (6) & $\mathrm{HBI}$ & $\begin{array}{l}\text { Enterobacter sp. } \\
\text { Bacillus subtilis subsp. subtilis } \\
\text { Micrococcus luteus }\end{array}$ & $0.886 \pm 0.032$ & ++++ \\
\hline consortium (7) & HBE & $\begin{array}{l}\text { Enterobacter sp. } \\
\text { Bacillus subtilis subsp. subtilis } \\
\text { Aerococcus sp. }\end{array}$ & $0.940 \pm 0.041$ & ++++ \\
\hline
\end{tabular}

${ }^{a}$ Data represents averages \pm standard deviation (SD) of duplicate samples after incubation for seven days.

bexcellent growth of bacteria $\left(\mathrm{OD}_{620}=0.81-1.0\right)$ denoted by ++++ indicating very high hydrocarbon-utilising capability; high growth of bacteria $\left(\mathrm{OD}_{620}=0.61-0.80\right)$ denoted by +++ indicating high hydrocarbon-utilising capability; moderate growth of bacteria $\left(\mathrm{OD}_{620}=0.41-\right.$ $0.60)$ denoted by ++ indicating moderate hydrocarbon-utilising capability; low growth of bacteria $\left(\mathrm{OD}_{620}=<0.40\right)$ denoted by + indicating low hydrocarbon-utilising capability

\section{CONCLUSION}

Ten hydrocarbon-utilising bacterial strains were isolated by enrichment technique from oil-polluted sites using crude oil as sole carbon source. The consortium consisting of three bacterial strains showing the best growth in diesel is recommended to be tested in future studies before applying in field. $B$. subtilis subsp. subtilis and Aerococcus sp. were isolated from crude oil polluted soil and Enterobacter sp. was isolated from diesel oil contaminated soil of a petrol station. It is expected that these indigenous hydrocarbon-utilising bacteria are more adapted to arid conditions and it is recommended that this consortium can be utilised in in situ landfarming remediation of oil-polluted sites to reduce concentrations of the contaminants to safe levels.

\section{ACKNOWLEDGEMENTS}

We gratefully acknowledge the financial support provided by the University of Khartoum to carry out this work. We appreciate the help of Khartoum Refinery Company for supplying 'Heglig Nile Blend' crude oil. We would like to express our sincere appreciation to the reviewers and members of the editorial team for their efforts, valuable comments and remarks. The authors are grateful to Professor N. Chrisofi, Emeritus Professor, Edinburgh Napier University, Scotland UK for reading the manuscript.

\section{REFERENCES}

Adebajo, M. O., Frost, R. L., Kloprogge, J. T., Carmody, O. M. and Kokot, S. (2003). Porous materials for oil spill cleanup: A review of synthesis and absorbing properties. Journal of Porous Materials 10(3), 159-170.

Adebusoye, S. A., Ilori, M. O., Amund, O. O., Teniola, O. D. and Olatope, S. O. (2007). Microbial degradation of petroleum hydrocarbons in a polluted tropical stream. World Journal of Microbiology and Biotechnology 23(8), 1149-1159.

Admon, S., Green, M. and Avnimelech, Y. (2001). Biodegradation kinetics of hydrocarbon in soil during land treatment of oily sludge. Bioremediation Journal 5(3), 193-209.

Ahirwar, S. and Dehariya, K. (2013). Isolation and characterization of hydrocarbon degrading 
microorganisms from petroleum oil contaminated soil sites. Bulletin of Environmental Science Research 2(4), 5-10.

Al-Daher, R., Al-Awadhi, N. and Al-Nawawy, A. (1998). Bioremediation of damaged desert environment using the windrow soil pile system in Kuwait. Environmental International 24(1,2) 175-180.

Al-Saleh, E., Drobiova, H. and Obuekwe, C. (2009). Predominant culturable crude oil-degrading bacteria in the coast of Kuwait. International Biodeterioration and Biodegradation 63(4), 400-406.

Asghar, H. N., Rafique, H. M., Zahir, Z. A., Khan, M. Y., Akhtar, M. J., Naveed, M. and Saleem, M. (2016). Petroleum hydrocarbons-contaminated soils: Remediation approaches. In: Soil Science: Agricultural and Environmental Prospectives. Hakeem, K. R., Aktar, J. and Sabir, M. (eds.). Springer, Cham. pp. 105-129.

Atlas, R. M. (1981). Microbial degradation of petroleum hydrocarbons, an environmental perspective. Microbiology Reviews 45, 180-209.

Atlas, R. M. (1991). Microbial hydrocarbon degradationBioremediation of oil spills. Journal of Chemical Technology and Biotechenology 52, 149-156.

Atlas, R. M. and Bartha, R. (1992). Hydrocarbon biodegradation and oil-spill bioremediation. In: Advances in Microbial Ecology. Marshall K. C. (ed.). Vol. 12, Plenum Press, New York. pp. 287-338.

Boboye, B., Olukunle, O. F. and Adetuyi, F. C. (2010). Degradative activity of bacteria isolated from hydrocarbon-polluted site in Ilaje, Ondo State, Nigeria. African Journal of Microbiology Research 4(23), 24842491.

Bouchez, M., Blanchet, D., Bardin, V., Haeseler, F. and Vandecasteele, J. P. (2000). Efficiency of defined strains and of soil consortia in the biodegradation of polycyclic aromatic hydrocarbon (PAH) mixtures. Biodegradation 10, 429-435.

Cappuccino, J. G. and Sherman, N. (2014). Microbiology: A Laboratory Manual. $10^{\text {th }}$ Edn. Pearson New York. pp. 544.

Cerqueira, V. S., Hollenbach, E. B., Maboni, F., Vainstein, M. H., Camargo, F. A. O., Peralba, M, C. R. and Bento, F. M. (2011). Biodegradation potential of oily sludge by pure and mixed bacterial cultures. Bioresource Technology 103, 1103-1110.

Chaillan, F., Le Fleche, A., Bury, E., Phantavong, Yhui, Grimont, P., Saliot, A. and Oudot, J.'(2004). Identification and biodegradation potential of tropical aerobic hydrocarbon degrading microorganisms. Research in Microbiology 155(7), 587-595.

Deschamps, G., Caruel, H., Borredon, M.-E., Bonnin, C., and Vignoles, C. (2003). Oil removal from water by selective sorption on hydrophobic cotton fibers. 1 . study of sorption properties and comparison with other cotton fiber-based sorbents. Environmental Science and Technology 37(5), 1013-1015.

Gallego, J. R., Garcıa-Martınez, M. J., Llamas, J. F., Belloch, C., Pelaez, A. I. and Sanchez, J. (2007).
Biodegradation of oil tank bottom sludge using microbial consortia. Biodegradation 18, 269-281.

Ganesh, A. and Lin, J. (2009). Diesel degradation and biosurfactant production by Gram-positive isolates. African Journal of Biotechnology 8(21), 5847-5854.

Holt, J. G., Krieg, N. R., Sneath, P. H. A., Staley, J. T. and Williams, S. T. (1994). Bergey's Manual of Systematic Bacteriology, $9^{\text {th }}$ Edn. Williams and Wilkins Company, Baltimore. pp. 1268.

Hunter, R. D., Ekunwe, S. I. N., Dodor, D. E., Hwang, H. M. and Ekunwe, L. (2005). Bacillus subtilis is a potential degrader of pyrene and benzo[a]pyrene. International Journal of Environmental Research and Public Health 2, 267-271.

ljah, U. J. J. and Antai, S. P. (2003). Removal of Nigerian light crude oil in soil over a 12-month period. International Biodeterioration and Biodegradation 51, 93-99.

Jasmine, J. and Mukherji, S. (2014). Evaluation of bioaugmentation and biostimulation effects on the treatment of refinery oily sludge using $2^{n}$ full factorial design. Environmental Science Processes Impacts 16, 1889-1896.

Khan, F. I., Husain, T. and Hejazi, R. (2004). An overview and analysis of site remediation technologies. Journal of Environmental Management 71, 95-122.

Koshlaf, K. and Ball, A. S. (2017). Soil bioremediation approaches for petroleum hydrocarbon polluted environments. AIMS Microbiology 3(1), 25-49.

Leahy, J. H. and Colwell, R. (1990). Microbial degradation of hydrocarbons in the environment. Microbiological Reviews 54(3), 305-315.

Lessard, R. R. and Demarco, G. (2000). The significance of oil spill dispersants. Spill Science Technology Bulletin 6, 59-68.

Limaa, S. D., Oliveiraa, A. F., Golina, R., Lopesa, V. C. P., Caixetaa, D. S., Limaa, Z. M. and Moraisa, E. B. (2019). Isolation and characterization of hydrocarbondegrading bacteria from gas station leakingcontaminated groundwater in the Southern Amazon, Brazil. Brazilian Journal of Biology 79, 1-8.

Lynch, J. M. and Moffat, A. J. (2005). Bioremediationprospects for the future application of innovative applied biological research. Annals of Applied Biology 146, 217-221.

Malallah, G., Afial, M., Kurian, M., Gulshan, S. and Dhami, M. S. I. (1998). Impact of oil pollution on some desert plants. Environment International 24(8), 919924.

Malik, Z. A. and Safia Ahmed, S. (2012). Degradation of petroleum hydrocarbons by oil field isolated bacterial consortium. African Journal of Biotechnology 11(3), 650-658.

Mikesková, H., Novotný, Č. and Svobodová, K. (2012). Interspecific interactions in mixed microbial cultures in a biodegradation perspective. Applied Microbiology and Biotechnology 95(4), 861-870.

Mishra, S., Jyot, J., Kuhad, R. C. and Lal, B. (2001). Evaluation of inoculum addition to stimulate in situ 
bioremediation of oily-sludge-contaminated soil. Applied and Environmental Microbiology 67(4), 16751681.

Morgan, P. and Watkinson, R. J. (1989). Hydrocarbon degradation in soils and methods for soil biotreatment. Crititical Review of Biotechnology 8, 305-333.

Nwaogu, L. A., Onyeze, G. O. and Nwabueze, R. N. (2008). Degradation of diesel oil in polluted soil using Bacillus subtilis. African Journal of Biotechnology 7(12), 1939-1943.

Omotayo, A. E., Ojo, O. Y. and Amund, O. O. (2012). Crude oil degradation by microorganisms in soil composts. Microbiology 7, 209-218.

Panda, S., Kar, R. and Panda, C. (2013). Isolation and identification of petroleum hydrocarbon degrading microorganisms from oil contaminated environment. International Journal of Environmental Science and Technology 3(5), 1314-1321.

Patowary, K., Patowary, R., Kalita, M. C. and Deka, S. (2016). Development of an efficient bacterial consortium for the potential remediation of hydrocarbons from contaminated sites. Frontiers in Microbiology 7, 1092-1105.

Rahman. K. S. M., Rahman, J. T., Lakshmanaperumalsamy, P. I. and Banat, M. (2002). Towards efficient crude oil degradation by a mixed bacterial consortium. Bioresource Technology 85, 257-261.

Roy, A. S., Baruah, R., Borah, M., Singh, A. K., Boruah, H. P. D., Saikia, N., Deka, M., Dutta, N. and Bora, T. C. (2014). Bioremediation potential of native hydrocarbon degrading bacterial strains in crude oil contaminated soil under microcosm study. International Biodeterioration and Biodegradation 94, 79-89.

Santisi, S., Cappello, S., Catalfamo, M., Mancini, G., Hassanshahian, M., Genovese, L., Giuliano, L. and Yakimov, M. M. (2015). Biodegradation of crude oil by individual bacterial strains and a mixed bacterial consortium. Brazilian Journal of Microbiology 46(2), 377-387.

Sarkar, P., Rai, A. R. and Ghosh, S. (2013). Degradation of aromatic petroleum hydrocarbons (BTEX) by a solvent tolerant bacterial consortium. Journal of Urban Environmental Engineering 7, 274-279.

Sarkar, P., Roy, A., Pal, S., Mohapatra, B., Kazy, S. K., Maiti, M. K. and Sar, P. (2017). Enrichment and characterization of hydrocarbon-degrading bacteria from petroleum refinery waste as potent bioaugmentation agent for in situ bioremediation. Bioresource Technology 242, 15-27.

Sathishkumer, M., Binupriya, A. R., Baik, S. H. and Yun, S-E. (2008). Biodegradation of crude oil by individual bacterial strains and mixed bacterial consortium isolated from hydrocarbon contaminated area. Clean-Soil, Air, Water 36(1), 92-96.

Schrader, E. L. (1991). Remediation of floating, open water oil spills: Comparative efficacy of commercially available polypropylene sorbent booms. Environmental Geology and Water Sciences 17, 157-166.
Singh, K. and Chandra, S. (2014). Treatment of petroleum hydrocarbon polluted environment through bioremediation: A review. Pakistan Journal of Biological Sciences 17(1), 1-8.

Survery, S., Ahmed, S., Subhan, S., Ajaz, M. and Rasool, S. A. (2004). Hydrocarbon degrading bacteria from Pakistani soil: Isolation, identification, screening and genetical studies. Pakistan Journal of Biological Science 7(9), 1581-1522.

Toledo, F. L., Calvo, C., Rodelas, B. and GonzalezLopez, J. (2006). Selection and identification of bacteria isolated from waste crude oil with polycyclic aromatic hydrocarbons removal capacities. Systematic and Applied Microbiology 29, 244-252.

Van Hamme, J. D., Singh, A. and Ward, O. P. (2003). Recent advances in petroleum microbiology. Microbiology and Molecular Biology Review 67, 503549.

Varjani, S. J., Rana, D. P., Jain, A. K., Bateja, S. and Upasani, V. N. (2015). Synergistic ex-situ biodegradation of crude oil by halotolerant bacterial consortium of indigenous strains isolated from on shore sites of Gujarat. India. International Biodeterioration and Biodegradation 103, 116-124.

Varjani, S. J. (2017). Microbial degradation of petroleum hydrocarbons. Bioresource Technology 223, 277-286.

Vinas, M., Grifoll, M., Sabate, J. and Solanas, A. M. (2002). Biodegradation of a crude oil by three microbial consortia of different origins and metabolic capabilities. Journal of Industrial Microbiology and Biotechnology 28, 252-260.

Wang, X. B., Chi, C. Q., Nie, Y., Tang, Y. Q., Tan, Y., $\mathrm{Wu}, \mathrm{G}$. and $\mathrm{Wu}, \mathrm{X}$. L. (2011). Degradation of petroleum hydrocarbons (C6-C40) and crude oil by a novel Dietzia strain. Bioresource Technology, 102(17), 7755-7761.

Xu, X., Liu, W., Tian, S., Wang, W., Qi-Q., Jiang, P., Gao, X., Li, F., Li, H. and Yu, H. (2018). Petroleum hydrocarbon-degrading bacteria for the remediation of oil pollution under aerobic conditions: A perspective analysis. Frontiers in Microbiology 9, 2885-2895.

Zajic, E. and Supplisson, B. (1972). Emulsification and degradation "Bunker C" fuel oil by microorganisms. Biotechnology and Bioengineering 14(3), 331-343. 